\title{
Transgenic tomatoes expressing human beta-amyloid for use as a vaccine against Alzheimer's disease
}

\author{
Jung Won Youm · Jae Heung Jeon · Hee Kim • \\ Young Ho Kim · Kisung Ko $\cdot$ Hyouk Joung • \\ HyunSoon Kim
}

Received: 9 May 2008/Accepted: 23 May 2008/Published online: 5 July 2008

(C) Springer Science+Business Media B.V. 2008

\begin{abstract}
Human $\beta$-amyloid $(\mathrm{A} \beta)$ is believed to be one of the main components of Alzheimer's disease, so reduction of $\mathrm{A} \beta$ is considered a key therapeutic target. Using Agrobacterium-mediated nuclear transformation, we generated transgenic tomatoes for $\mathrm{A} \beta$ with tandem repeats. Integration of the human $\mathrm{A} \beta$ gene into the tomato genome and its transcription were detected by PCR and Northern blot, respectively. Expression of the $\mathrm{A} \beta$ protein was confirmed by western blot and ELISA, and then the transgenic tomato line expressing the highest protein level was selected for vaccination. Mice immunized orally with total soluble extracts from the transgenic tomato plants elicited an immune response after receiving a booster. The results indicate that tomato plants may provide a useful system for the production of human $\mathrm{A} \beta$ antigen.
\end{abstract}

Keywords Alzheimer's disease - Edible vaccine · Immunogenicity · Tomato-derived beta amyloid

J. W. Youm · J. H. Jeon · H. Joung $\cdot$ H. S. Kim $(\bowtie)$ Plant Genomics Research Center, KRIBB, 111 Gwahangno, Yuseong-gu, Daejeon 305-806, Korea e-mail: hyuns@kribb.re.kr

H. Kim · Y. H. Kim

Digital Biotech Inc., R\&D, 1227, SinGil Dong, AnSan City, KyungGiDo 425-839, Korea

K. Ko

Department of Biological Science, College of Natural Sciences, Wonkwang University, Iksan, Chonbuk, Korea

\section{Introduction}

Alzheimer's disease (AD) is a neurodegenerative disease and the most common cause of dementia which progresses over a prolonged period. According to what is currently known about $\mathrm{AD}$, it is believed to be caused by the accumulation of beta-amyloid (A $\beta)$, a toxic protein, in the brain. This ultimately results in neuronal death (Taylor et al. 2002; Hardy and Salkoe 2002). Therefore, an effective strategy for the prevention and treatment of the underlying causes of $\mathrm{AD}$ would be to develop an agent that inhibits the degeneration of the nervous system via the suppression of $\mathrm{A} \beta$ generation, thus circumventing its associated toxicity. Reducing the accumulation of A $\beta$ may prevent or delay the onset of Alzheimer's disease. In a recent study, a variety of vaccination advances were made using the $\mathrm{A} \beta$ peptide. Schenk et al. (1999) and Morgan et al. (2000) immunized transgenic mice with purified $\mathrm{A} \beta$ and raised an antibody against the 42 -amino acid form of $\mathrm{A} \beta$.

It is difficult to produce $\mathrm{A} \beta$ through $E$. coli or yeast expression systems because of the toxicity of the protein. For this reason, the possibility of $\mathrm{A} \beta$ expression in plant cells was investigated. Transgenic plants are considered to be an alternative system for the useful production of recombinant proteins, such as antibodies, antigens, and therapeutics. During the last 15 years, various antigens have been successfully produced in plants and orally delivered to animals resulting in induced immune responses (Mason et al. 
1996; Tacket et al. 1998; Richter et al. 2000). The first step was examining the effect of plant-derived $\mathrm{A} \beta$ on the induction of an immune response in transgenic mice (Youm et al. 2005). Immunization with potato-derived $5 \mathrm{~A} \beta 42$ can reduce the $\mathrm{A} \beta$ burden as well as many of the pathological features found in a transgenic $\mathrm{AD}$ mouse model.

Various crops have been used to develop plantderived antigens. Each plant has advantages and disadvantages (Sala et al. 2003). Plants such as tobacco and alfalfa often produce proteins in their green leaf tissues, but these tend to contain high concentrations of phenolic and other potentially toxic compounds. Seeds are likely to have fewer phenolic compounds and a less complex mixture of proteins and lipids than green leaves, which might be an advantage during purification. In the case of the tomato plant, tomatoes can be eaten without heat treatment, which may destroy the immunogenicity of the antigen. Furthermore, transgenic tomatoes are exhibiting considerable potential for the economic production of proteins, with a few already being marketed (Horn et al. 2004).

In the current study, we carried out the cloning and expression of three to five tandem repeats forms of $\mathrm{A} \beta$ in tomato plants in an attempt to develop a plantderived $\mathrm{AD}$ vaccine. The ability of tomato-derived A $\beta$ antigen to evoke antibody responses in mice was analyzed. Immunized mice produced serum antibodies against the $\mathrm{A} \beta$ antigen. We confirmed that it is feasible to produce the $\mathrm{A} \beta$ protein in transgenic tomatoes and to serve as a novel delivery system for the oral immunization of BALB/c mice.

\section{Materials and methods}

Plant material

Agrobacterium-mediated transformation of the tomato was carried out with the Housechallenge cultivar as described by Frary and Hamilton (2001). Seeds were sterilized with $15 \%$ sodium hypochloride solution for $10 \mathrm{~min}$ and washed 2-3 times with sterile distilled water. Sterilized seeds were cultivated on MS tissue culture medium (Murashige and Skoog 1962 ) at $25^{\circ} \mathrm{C}$ with $16 \mathrm{~h}$ of light a day. Ten days later, fully expanded cotyledons were used for the plant transformation.
Tomato transformation and regeneration

Vector constructs were used as described in previous work (Youm et al. 2005). Briefly, the tandemrepeated (3-mer to 5-mer, Fig. 1a) A $\beta$ cDNAs were introduced into pMBP1, which yielded pMBPn (3-5)A $\beta$ vectors (Fig. 1b). Cotyledons were cut in two pieces and incubated with $A$. tumefaciens suspension and $75 \mathrm{mM}$ acetosyringon for $20 \mathrm{~min}$ with occasional gentle shaking. After drying off the excess liquid from the bacterial suspension with sterile filter paper, the explants were placed upside down onto Petri dishes containing MS medium supplemented with

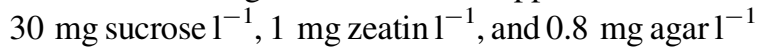

(a)

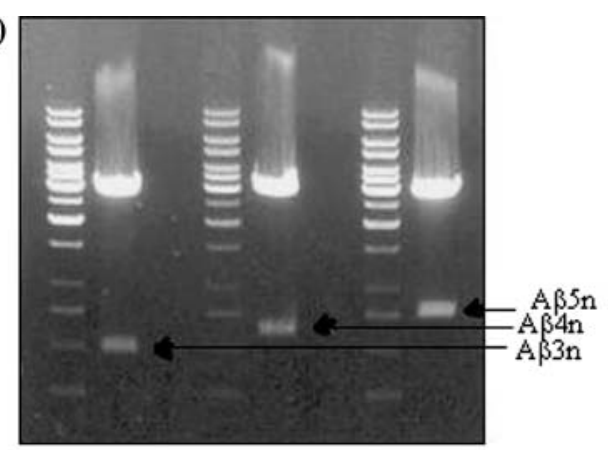

(b)

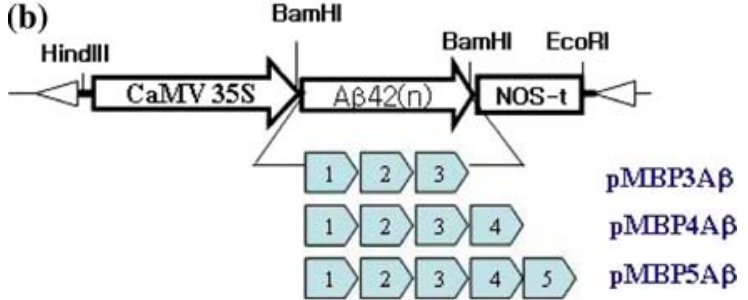

(c)

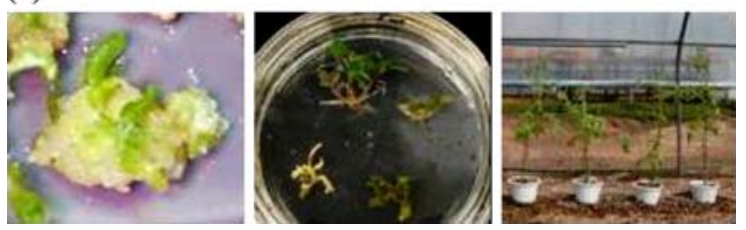

Fig. 1 Construction of expression vectors and generation of transgenic tomatoes. (a) Each multimer of $\mathrm{A} \beta$ was visualized in agarose gel stained with ethidium bromide. (b) Schematic diagram of the plant expression vectors. The $3 \mathrm{~A} \beta, 4 \mathrm{~A} \beta$, and $5 \mathrm{~A} \beta$ genes were cloned under the control of the CaMV35S promoter, which yielded $\mathrm{pMBP} 3 \mathrm{~A} \beta, \quad \mathrm{pMBP} 4 \mathrm{~A} \beta$, and pMBP5A $\beta$, respectively. (c) In-vitro shoots regenerating from cotyledon-disc callus (left). Transformants were selected on MS medium containing $100 \mathrm{mg}$ kanamycin $\mathrm{l}^{-1}$ (middle). Transgenic plants were then established in the greenhouse (right) 
without antibiotics. Two days later, the explants were transferred on to MS agar medium containing $2 \mathrm{mg}$ zeatin $1^{-1}, 100 \mathrm{mg}$ kanamycin $1^{-1}$, and $1,000 \mathrm{mg}$ carbenicillin $1^{-1}$. The dishes were placed in a growth chamber with a $16 \mathrm{~h}$ photoperiod at $25^{\circ} \mathrm{C}$, and the medium was changed every 4 weeks. Regenerated shoots were separated from calli forming on the explants and cultured on MS medium with $50 \mathrm{mg}$ kanamycin $1^{-1}$ and $500 \mathrm{mg}$ carbenicillin $1^{-1}$. The transformants were transferred to the greenhouse to grow as whole plants. Morphological characteristics, such as shoot growth and fruit on the transgenic plants, were compared with those of non-transgenic plants. Hormones and antibiotics were purchased from Duchefa co. (Haarlem, The Netherlands).

PCR analysis and Southern hybridization

The presence of inserted DNA in the tomato genome was cross-checked by PCR analysis for both the neomycin phophotransferase II (npt II) and $\mathrm{A} \beta$ gene. PCR analysis for the npt II gene was performed as described previously (Kim et al. 2003). Total genomic DNA from non-transformed (NT) plants was used as a negative control and all putative kanamycin resistant plants were extracted as described by Doyle and Doyle (1987). A $20 \mu \mathrm{l}$ PCR reaction mix contained $100 \mathrm{ng}$ of each primer, premix solution (Bioneer Co., Korea), and $100 \mathrm{ng}$ genomic DNA as template. Cycling conditions were $94^{\circ} \mathrm{C}$ for $45 \mathrm{~min}, 65^{\circ} \mathrm{C}$ for $30 \mathrm{~min}$, and $72^{\circ} \mathrm{C}$ for $30 \mathrm{~min}$ for a total 25 cycles. The primer sequences used to amplify the $\mathrm{A} \beta$ gene were $5^{\prime}$-GGA TCC ATG GAT GCA GAA TCC CGA CAT GAC- $3^{\prime}$ and 5'-GGA TCC TCA CGC TAT GAC AAC ACC GCC CAC- $3^{\prime}$. The amplified DNA fragments were separated by electrophoresis on a $1.5 \%$ agarose gel and visualized by ethidium bromide staining.

\section{Northern blot analysis}

Total RNA from the leaves of NT plants and transformed plants was isolated using the RNAgents Total RNA isolation system (Promega, WI, USA) according to the manufacturer's instructions. Thirty $\mu \mathrm{g}$ total RNA was denatured with formaldehyde and formamide, fractionated in a $1 \%$ agarose gel using MOPS buffer and then blotted to a positively charged nylon membrane. The membranes were hybridized with Dig-labeled $\mathrm{A} \beta$-specific probe at $68^{\circ} \mathrm{C}$ overnight and detected using the Dig Detection kit (Roche Co., Germany).

Western and ELISA analysis to detect $\mathrm{A} \beta$ protein

Protein extraction and analysis of $3 \mathrm{~A} \beta$-expressing lines were performed as described in previous studies (Kim et al. 2003; Youm et al. 2005). Total soluble protein (TSP) was extracted from NT control and transgenic tomato plants by homogenizing in extraction buffer, and quantified by the Bradford method.

Western blot analysis was performed using antiA $\beta$ monoclonal antibody, 4G8 (1:5,000 dilution, Signet Lab., MA, USA). A chemiluminiscence kit (Amersham Bioscience, UK) was used to visualize the specific bands. The recombinant $3 \mathrm{~A} \beta$ protein levels were determined via direct ELISA assays. The ELISA plate were coated with $100 \mu \mathrm{g}$ TSP in $0.05 \mathrm{M}$ carbonate/bicarbonate $(\mathrm{pH} 9.6)$ buffer and incubated with anti-A $\beta$ monoclonal antibody $(6 \mathrm{E} 10,1: 1,000$ dilution, Signet Lab.). The amount of $\mathrm{A} \beta$ proteins in TSP was estimated with $\mathrm{A} \beta 42$ peptide as a standard.

Vaccination of Balb/c mice with transformed plant extract

A group of 15 month old Balb/c mice was used in the immunization experiments. Ten mice from each group were fed extracts from transgenic tomato line pMBP $3 \mathrm{~A} \beta-6$ or NT control plants plus $10 \mu \mathrm{g}$ Cholera Toxin B subunit (CTB) (Sigma) once a week for 3 weeks. Prior to the oral immunizations, $0.2 \mathrm{ml}$ sodium bicarbonate was applied by gastric gavage to each of the mice, in order to neutralize stomach acidity. Blood samples were collected just before the examination (day 0) and after primary immunization. Each mouse was given a booster at 4 weeks after the 3rd feeding with $15 \mu \mathrm{g}$ of synthetic $\mathrm{A} \beta$ peptide emulsified in alum. Sera were collected from the mice 2 weeks after boosting, and all blood samples were analyzed by ELISA assays.

Direct ELISA for anti-A $\beta$ antibody production

Flat-bottom ELISA plates were coated overnight at $4^{\circ} \mathrm{C}$ with $\mathrm{A} \beta 42(0.1 \mu \mathrm{g} /$ well of $0.05 \mathrm{M}$ carbonate/ bicarbonate buffer, $\mathrm{pH}$ 9.6) to measure the titers of anti-A $\beta$ antibodies in the sera of immunized mice. Most of the procedures were the same as previously 
described (Youm et al. 2005). Briefly, the coated plates were incubated with serum samples, diluted 1:100 in blocking buffer, for $2 \mathrm{~h}$ at room temperature. The plates were then incubated with mouse IgGconjugated horseradish peroxidase (secondary antibody), diluted 1:1,000 in blocking buffer, for $2 \mathrm{~h}$ at room temperature. To stop the reaction, $100 \mu \mathrm{l}$ tetramethylbenzidine substrate (Pierce, IL, USA) and $\mathrm{H}_{2} \mathrm{O}_{2}$ were added. After incubation, the reaction was measured at $450 \mathrm{~nm}$ with an ELISA reader.

\section{Results}

Generation of transgenic tomato plants

Three multimer forms of $\mathrm{A} \beta$, trimer to pentamer, were successfully introduced into the pMBP1 vector. The immunogenicity of each multimer form of synthetic $\mathrm{A} \beta$ was determined by western blot with an anti-A $\beta$ antibody. Four weeks after co-cultivation, shoots were developed from cotyledon-disc segments (Fig. 1c, left) and putative transformants selected through kanamycin resistance (Fig. 1c, middle). We obtained more than 20 individual plantlets and carried out further analysis of $\mathrm{A} \beta$ expression on selected transgenic plants. Non-transformed tomato plants regenerated from non-contaminated cotyledon discs were used as negative controls. The selected transformants exhibited similar growth with no phenotypic abnormalities compared to the NT plants (Fig. 1c, right).

\section{Analysis of $\mathrm{A} \beta$ expression in tomato transformants}

The presence of $n p t$ II in the genomic DNA isolated from transformants and NT tomato plants was detected by PCR amplification (data not shown). The expected $\mathrm{A} \beta$-specific bands of approximately 450,600 , and $750 \mathrm{bp}$ were seen in the transformants, respectively (Fig. 2a). No DNA product was detected in NT plant. Selecting the transformants by PCR analysis, we determined the insertion of three to five repeated $\mathrm{A} \beta$ genes into the genomic DNA of these tomato plants.

The transcription of $3 \mathrm{~A} \beta, 4 \mathrm{~A} \beta$, and $5 \mathrm{~A} \beta$ DNA in transgenic plants was determined by Northern analysis. Fig. $2 \mathrm{~b}$ shows the results of an experiment where selected transformants harboring the $\mathrm{pMBPn}(3-5) \mathrm{A} \beta$
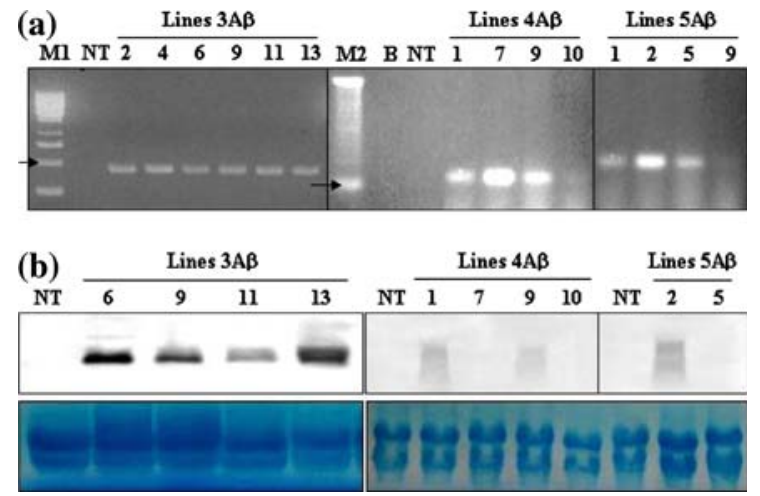

Fig. 2 PCR and Northern blot analysis of the $\mathrm{A} \beta$ transgenic lines (a) PCR analysis for the presence of $\mathrm{A} \beta$ gene in transgenic tomato plants. Plant DNA was isolated from leaf extracts and PCR was performed with a pair of primers which specifically amplify a $3 \mathrm{~A} \beta, 4 \mathrm{~A} \beta$, and $5 \mathrm{~A} \beta$ fragments. $\mathrm{M} 1,1 \mathrm{~kb}$ marker; M2, 100bp marker; NT, non-transformed plant as negative control; each numbers represent independent transgenic lines carrying expression cassette for $3 \mathrm{~A} \beta, 4 \mathrm{~A} \beta$, or $5 \mathrm{~A} \beta$. Arrows indicate 500bp. (b) Detection of $\mathrm{A} \beta$ mRNA in transgenic plants. Twenty five $\mu \mathrm{g}$ of total RNA from NT and selected independent lines by PCR analysis were loaded on $1.0 \%$ formaldehyde agarose gel and hybridized by an $\mathrm{A} \beta$ specific Dig-labeled probe

constructs and a NT control were probed. An A $\beta$ specific RNA was found in six lines of transgenic $3 \mathrm{~A} \beta$, two lines of transgenic $4 \mathrm{~A} \beta$, and one line of transgenic $5 \mathrm{~A} \beta$, but at quite different levels.

Based on Northern analysis, only transgenic $3 \mathrm{~A} \beta$ lines were further analyzed for recombinant protein expression by western blotting and ELISA analysis using a monoclonal specific antibody. The TSPs were extracted from leaves of the individual transgenic tomato lines $3 \mathrm{~A} \beta-6$ and -9 . Transgenic potato line pMBP5A $\beta-1$ (Youm et al. 2005) was used as positive control to detect $\mathrm{A} \beta$-specific protein in the transgenic tomatoes. We confirmed the highest level of 3 tandemerized $\mathrm{A} \beta$ protein in transgenic line $3 \mathrm{~A} \beta-6$ (Fig. 3a). Using direct ELISA analysis, we quantified the level of $3 \mathrm{~A} \beta$ protein expression in the transgenic plants expressing pMBP3A $\beta$ vectors (Fig. $3 b$ ). The expression of recombinant $\mathrm{A} \beta$ protein in lines $3 \mathrm{~A} \beta-6$ and -9 were 80 and $58 \mathrm{ng} / \mathrm{ml}$ in the applied extract, respectively.

Immunogenicity of tomato-derived $3 \mathrm{~A} \beta$

In our previous report (Youm et al. 2005), mice immunized with potato-derived $5 \mathrm{~A} \beta$ developed primary 

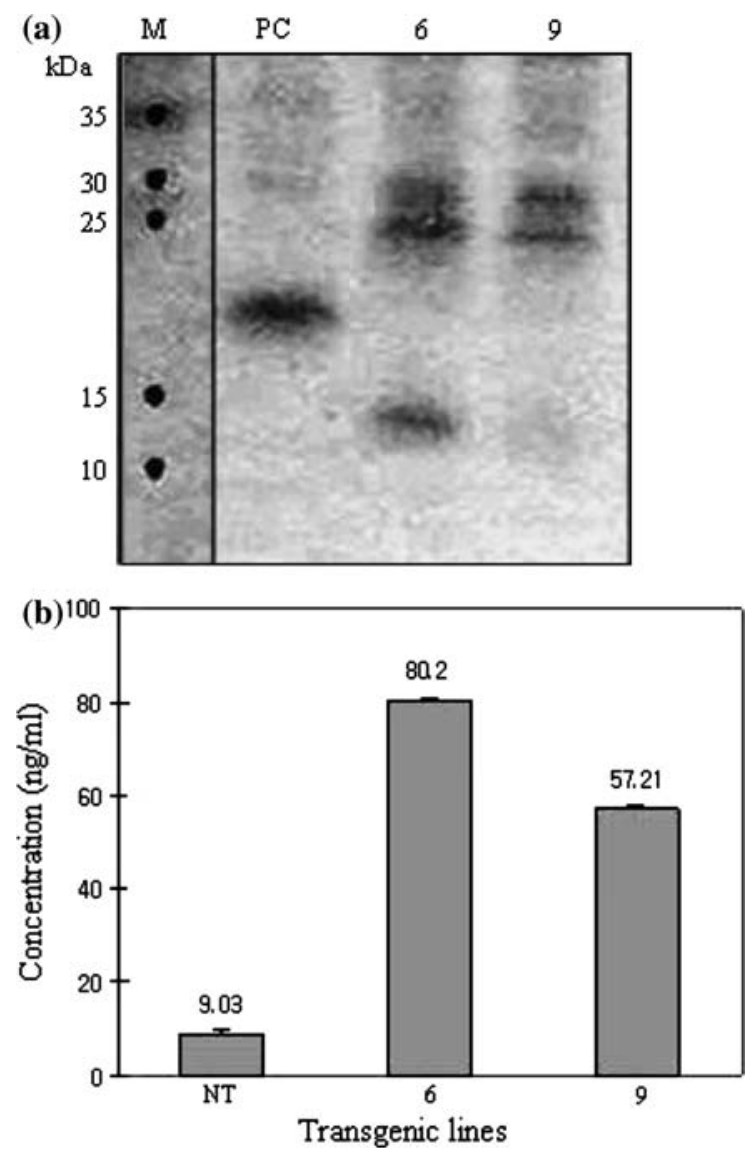

Fig. 3 Analysis of tomato-derived $3 \mathrm{~A} \beta$ protein. (a) Western blot analysis of transgenic tomato lines. An equal amount of total soluble protein (TSP) from two transgenic plant lines $3 \mathrm{~A} \beta-6$ and -9 were loaded and the $3 \mathrm{~A} \beta$ protein was detected by anti-A $\beta$ monoclonal antibody, 4G8. Transgenic potato line M5A $\beta$ - 1 was used as positive control (PC) to detect $\mathrm{A} \beta$ specific protein in transgenic tomato. (b) Quantitative analysis of expressed $3 \mathrm{~A} \beta$ in transgenic tomato plants using direct ELISA with each transgenic plant TSP and anti-A $\beta$ monoclonal antibody, $6 \mathrm{E} 10$. The amount of $3 \mathrm{~A} \beta$ proteins in TSP was calculated using $\mathrm{A} \beta 42$ peptide as a standard. Each bar represents an average of three samples \pm standard error

serum antibody and exhibited a partial reduction in the $\mathrm{A} \beta$ burden of the brain. In the present study, we attempted to determine whether the $3 \mathrm{~A} \beta$ generated in a transgenic tomato was able to induce an immune response in Balb/c mice. In groups of ten, Balb/c mice were immunized with extracts from transgenic line $3 \mathrm{~A} \beta-6$ or NT plants. The protein was extracted from $5 \mathrm{~g}$ tomato plants and freeze-dried yielding a total of $0.2 \mathrm{ml}$ concentrate. Mice were treated three times at weekly intervals and boosted 7 weeks after the initial feeding with $15 \mu \mathrm{g}$ of synthetic $\mathrm{A} \beta 42$ peptide emulsified

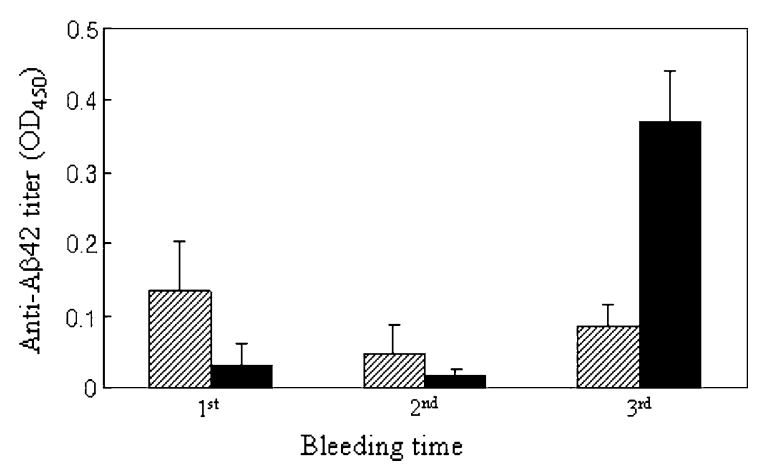

Fig. 4 Immunization of Balb/c mice with tomato-derived $3 \mathrm{~A} \beta$ resulted in anti-A $\beta$ antibody responses subsequent to the oral uptake of transgenic plant materials. Mice were gavaged by extracts from either non-transfromed (NT) plants (slash line bar) or transgenic line $3 \mathrm{~A} \beta-6$ (black bar) with CTB adjuvant. Bleeding time constitutes just before the examination (1st); after primary immunization, which was three times with weekly intervals (2nd); and after a booster at 7 weeks (3rd). Each bar represents an average of immunized mice \pm standard error

in alum. In order to determine the anti-A $\beta$ response, we collected sera on day 0 , before antigen inoculation, as a control; after the third feeding; and after the booster. The sera of the mice immunized with NT plant extract exhibited no induction of cross-reactive antibodies (Fig. 4). On the hand, mice fed the extract from transgenic tomato line $3 \mathrm{~A} \beta-6$ exhibited a significant increase in serum reactivity against $\mathrm{A} \beta$ after boosting, particularly in the levels of serum $3 \mathrm{~A} \beta$ specific antibodies.

\section{Discussion}

The expression levels were different between the various transform ants and can be different between organs of the same plant, which depends on the site the foreign DNA is inserted into the plant genome. Ma et al. (2003) reported that the expression of HEV in tomato fruits $(61 \mathrm{ng} / \mathrm{g}$ fresh weight) is higher than in leaves, and is similar to that of Bag in transgenic tomatoes (Lou et al. 2007). The higher expression of target protein in edible tissue may be helpful for producing an oral vaccine. In this study, a high level of $\mathrm{A} \beta$ transcript was found in the transgenic $3 \mathrm{~A} \beta$ lines, with a lower expression of the transgenic $4 \mathrm{~A} \beta$ and $5 \mathrm{~A} \beta$ lines than expected. It is not caused by the multimer form of $\mathrm{A} \beta$, because we previously showed 
good expression of the 5-mer in the potato (Youm et al. 2005).

An advantage of using tomatoes as an oral vaccine vector is that the tomato is a freshly eaten fruit, meaning it is possible to acquire immunity at the same time as enjoying food. However, the accumulation of protein in the tomato itself is low as it contains only $0.7 \%$ protein in the fresh fruit and the expression levels of foreign protein are much lower. In the context of this study, tomato-derived $3 \mathrm{~A} \beta$ is expressed at lower levels than potato-derived $5 \mathrm{~A} \beta$ using the same vector system. This will make it difficult when administering the plant-derived vaccine. To resolve this problem, the use of stronger promoters, plantderived leader sequences and signal peptides, plantoptimized synthetic genes, and targeting the protein for retention in the appropriate tissue (Stoical et al. 2003; Tackaberry et al. 2003; Lauterslager et al. 2001) have been investigated. In our previous study, $5 \mathrm{~A} \beta$ protein was increased up to $0.1 \%$ of TSP by introducing a strong promoter, signal peptide, and retention signal into the expression vector (Youm et al. 2005). All of these studies provided successful experiences in improving the expression level of antigen in transgenic tomatoes. In the present study, we introduced cDNA encoding $3 \mathrm{~A} \beta$ into the pMBP1 expression vector driven by the CaMV $35 \mathrm{~S}$ promoter without any enhancing factor, though there were many reconstruction possibilities to achieve high expression. We are currently engaged in research for increasing the expression level of foreign proteins using a tissue-specific promoter or signal peptide for subcellular localization.

In several reports, an immediate and strong secondary antibody response was observed in animals receiving a boost of commercial vaccine (Richter et al. 2000; Kong et al. 2001). Memory immune cells had apparently been established as a result of oral immunization. Our results in this study showed that mice fed extract from transgenic tomato line $3 \mathrm{~A} \beta-6$ exhibited a significant increase in serum against $\mathrm{A} \beta$ after boosting compared to the primary antibody response. Although we did not reveal a reduction of existing plaques in the brain of mice challenged with tomato-derived $3 \mathrm{~A} \beta$, we expect a similar result to what was found in our previous study (Youm et al. 2005) induced serum antibodies affect amyloid plaques in the brain resulting in a reduction in amyloid number or amyloid burden in the brain
(Schenk et al. 1999; Morgan et al. 2000; Youm et al. 2005).

One promising approach to the prevention and treatment of $\mathrm{AD}$ is based upon stimulating the immune system to reduce $\mathrm{A} \beta$ in the brain. There is still much optimism in regard to the eventual development of a vaccine strategy using $\mathrm{A} \beta$ (Gelinas et al. 2004). This study constitutes another example of active immunization, and also represents a unique approach in which transgenic plants expressing $\mathrm{A} \beta$ protein are used to produce the vaccine.

Acknowledgments This research was supported by a grant from the Plant Diversity Research Center of the 21st Century Frontier Research Program funded by the Ministry of Education and Science of the Korean government.

\section{References}

Doyle JJ, Doyle JL (1987) A rapid DNA isolation procedure for small quantities of fresh leaf tissue. Phytochem Bull 19:11-15

Frary A, Hamilton CM (2001) Efficiency and stability of high molecular weight DNA transformation: an analysis in tomato. Transgenic Res 10:121-132

Gelinas DS, DaSilva K, Fenli D, George-Hyslop P, McLaurin J (2004) Immunotherapy for Alzheimer's disease. Proc Natl Acad Sci USA 101:14657-14662

Hardy J, Selkoe DJ (2002) The amyloid hypothesis of Alzheimer's disease: progress and problems on the road to therapeutics. Science 297:353-356

Horn ME, Woodard SL, Howard JA (2004) Plant molecular farming; systems and products. Plant Cell Rep 22:711720

Kim HS, Euym JW, Kim MS, Lee BC, Mook-Jung I, Jeon JH, Joung H (2003) Expression of human beta-amyloid peptide in transgenic potato. Plant Sci 165:1445-1451

Kong Q, Richer L, Yang YF, Arntzen CJ, Mason HS, Tanavala Y (2001) Oral immunization with hepatitis B surface antigen expressed in transgenic plants. Proc Natl Acad Sci USA 98:11539-11544

Lauterslager TGM, Florack DEA, van der Wal TJ, Molthoff JW, Langeveld JPM, Bosch D, Boersma WJA, Hilgers LAT (2001) Oral immunisation of naive and primed animals with transgenic potato tubers expressing LT-B. Vaccine 19:2749-2755

Lou XM, Yao QH, Zhang Z, Peng RH, Xiong AS, Wang HK (2007) Expression of the human hepatitis B virus large surface antigen gene in transgenic tomato plants. Clin Vaccine Immunol 14:464-469

Ma Y, Lin SQ, Gao Y, Li M, Luo WX, Zhang J, Xia NS (2003) Expression of ORF2 partial gene of hepatitis E virus in tomatoes and immunoactivity of expression products. World J Gastroenterol 9:2211-2215

Mason HS, Ball JM, Shi JJ, Jiang X, Estes MK, Arntzen CJ (1996) Expression of Norwalk virus capsid protein in 
transgenic tobacco and potato and its oral immunogenicity in mice. Proc Natl Acad Sci USA 93:5335-5340

Morgan D, Diamond DM, Gottschall PE, Ugen KE, Dickey C, Hardy J, Duff K, Jantzen P, DiCarlo G, Wilcock D, Connor K, Hatcher J, Hope C, Gordon M, Arendash GW (2000) A $\beta$ peptide vaccination prevents memory loss in an animal model of Alzheimer's disease. Nature 408:982985

Murashige T, Skoog F (1962) A revised medium for rapid growth and bioassays with tobacco tissue culture. Physiol Plant 15:473-479

Richter LJ, Thanavala Y, Arntzen CJ, Mason HS (2000) Production of hepatitis B surface antigen in transgenic plants for oral immunization. Nat Biotechnol 18:1167-1171

Sala F, Rigano MM, Barbante A, Basso B, Walmsley AM, Castiglione S (2003) Vaccine antigen production in transgenic plants: strategies, gene constructs and perspectives. Vaccine 21:803-808

Schenk D, Barbour R, Dunn W, Gordon G, Grajeda H, Guido T, Hu K, Huang J, Johnson-Wood K, Khan K, Kholodenko D, Lee D, Liao Z, Lieberburg I, Motter R,Mutter L, Sorano F, Shopp G, Vasquez N, Vandevert C, Walker S, Woqulis M, Yednock T, Games D, Seubert P (1999)
Immunization with amyloid- $\beta$ attenuates Alzheimer's disease-like pathology in the PDAPP mouse. Nature 199:173-177

Sojikul P, Buehner N, Mason HS (2003) A plant signal peptide-hepatitis B surface antigen fusion protein with enhanced stability and immunogenicity expressed in plant cells. Proc Natl Acad Sci USA 100:2209-2214

Tackaberry ES, Prior F, Bell M, Tocchi M, Porter S, Mehic J, Ganz PR, Sardana R, Altosaar I, Dudani A (2003) Increased yield of heterologous viral glycoprotein in the seeds of homozygous transgenic tobacco plants cultivated underground. Genome 46:512-526

Tacket CO, Mason HS, Losonsky G, Clements JD, Levine MM, Arntzen CJ (1998) Immunogenicity in humans of a recombinant bacterial antigen delivered in a transgenic potato. Nature Med 4:607-609

Taylor JP, Hardy J, Fischbeck KH (2002) Toxic proteins in neurodegenerative disease. Science 296:1991-1995

Youm JW, Kim H, Han JHL, Jang CH, Ha HJ, Mook-Jung I, Jeon JH, Choi CY, Kim YH, Kim HS, Joung H (2005) Transgenic potato expressing $\mathrm{A} \beta$ reduce $\mathrm{A} \beta$ burden in Alzheimer's disease mouse model. FEBS Lett 579:67376744 